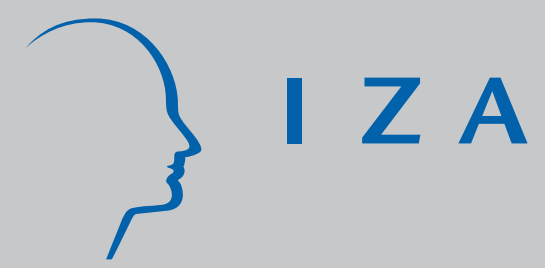

IZA DP No. 7260

Is Germany the North Star of Labor Market Policy?

Ulf Rinne

Klaus F. Zimmermann

March 2013

Forschungsinstitut zur Zukunft der Arbeit Institute for the Study of Labor 


\title{
Is Germany the North Star of Labor Market Policy?
}

\author{
Ulf Rinne \\ IZA \\ Klaus F. Zimmermann \\ IZA and University of Bonn
}

Discussion Paper No. 7260

March 2013

IZA
P.O. Box 7240
53072 Bonn
Germany

Phone: +49-228-3894-0

Fax: +49-228-3894-180

E-mail: iza@iza.org

Any opinions expressed here are those of the author(s) and not those of IZA. Research published in this series may include views on policy, but the institute itself takes no institutional policy positions. The IZA research network is committed to the IZA Guiding Principles of Research Integrity.

The Institute for the Study of Labor (IZA) in Bonn is a local and virtual international research center and a place of communication between science, politics and business. IZA is an independent nonprofit organization supported by Deutsche Post Foundation. The center is associated with the University of Bonn and offers a stimulating research environment through its international network, workshops and conferences, data service, project support, research visits and doctoral program. IZA engages in (i) original and internationally competitive research in all fields of labor economics, (ii) development of policy concepts, and (iii) dissemination of research results and concepts to the interested public.

IZA Discussion Papers often represent preliminary work and are circulated to encourage discussion. Citation of such a paper should account for its provisional character. A revised version may be available directly from the author. 


\section{ABSTRACT}

\section{Is Germany the North Star of Labor Market Policy?*}

Germany's recovery from an unemployment disease and its resilience to the Great Recession is remarkable. Its success story makes it a showcase for labor policy and labor market reforms. This paper assesses the potential of the German experience as a model for effective, evidence-based policymaking. Flexible management of working time (through overtime and short-time work, time accounts and labor hoarding), social cohesion and controlled unit labor costs, combined with a rigid, incentive-oriented labor policy supported by effective program evaluation, define the characteristics of a strong reference model. Austerity, sometimes seen as core to the German model, is not viewed as a key element.

JEL Classification: J68, J21, P52, O57

Keywords: labor market reforms, labor policy, unemployment, Great Recession, Germany, austerity

Corresponding author:

Klaus F. Zimmermann

IZA

P.O. Box 7240

53072 Bonn

Germany

E-mail: Zimmermann@iza.org

\footnotetext{
* The second author has advised Chancellor Gerhard Schröder and Economics and Labor Minister Wolfgang Clement at the time of the German labor market reforms on a personal (non-profit) level. Mr. Schröder provided his famous labor policy turnaround speech on March 14, 2003. We devote this paper to the 10th anniversary of this historical speech. Note that during the time of the reform debate, IZA initiated a public declaration in support of the reforms by 300 economists (IZA, 2003); a comprehensive reform agenda is outlined in Zimmermann (2003). Both authors wish to thank Amelie F. Constant and Stephan G. Richter for helpful comments and suggestions.
} 
The so-called "German model" has recently been the subject of great interest, both inside and outside the policy community. The country has not only successfully managed to escape the unemployment trap it was caught in for a couple of decades, it also performed exceptionally well during and after the Great Recession. This made Germany the North Star for effective labor market policies and reforms. Hence, it is not surprising that the concepts underlying the German model are now viewed as a possible reference model for other countries with labor market turmoil. The question for policymakers in other countries is thus whether Germany's success is just a matter of "luck," or whether its specific combination of a flexible management of working time (through overtime and short-time work, time accounts and labor hoarding), social cohesion and controlled unit labor costs, combined with a rigid, incentive-oriented labor policy supported by effective program evaluation, provide a set of guiding principles for labor market policies that can be successfully applied in other countries?

This paper sheds light on this important question. Section I describes Germany's initial economic situation as Europe's "sick man" caught in the unemployment trap. Section II provides an overview about the country's subsequent labor market reforms and highlights the elements that helped reestablish the country's international competiveness. Section III analyzes the recent Great Recession that served as the litmus test for the robustness of the German economy and the vigor of its labor market. Section IV studies the extent to which the labor market reforms and policy responses during the crisis were combined with fiscal consolidation and austerity. The concluding Section V summarizes and derives lessons from the German experience. 


\section{Germany's Structural Unemployment Problem}

For many years, the key challenge for Germany was to reduce structural and persistent unemployment. Overcoming its high level of unemployment was crucial for the "sick man" in Europe. The phenomenon of successive, recession-related waves of unemployment that ended up accumulating was considered to be a European problem (Blanchard and Summers, 1986). But among the countries in Europe, Germany served as the prime example for the pattern of high and rising unemployment. Figure 1 demonstrates that this alarming characteristic of Germany's labor market was present since the 1970s, and that German reunification, which began in 1990, further aggravated the problem.

$$
<<<\text { Figure } 1 \text { about here }>>>
$$

A number of policy measures addressed these problems in the 1990s, but the outcome was far from satisfactory. These adjustments barely managed the symptoms and did not deal with the roots of the problems; and at the turn of the century, the unemployment rate was among the highest in Europe. The country's high unemployment rate has often been linked to high levels of employment protection, high labor costs, and strict regulation of labor markets. Although the availability of rather generous insurance-based social benefits-depending on previous wages - helped limit income inequality and wage dispersion, these results came at the cost of strong labor market segmentation and a large stock of long-term unemployed (Eichhorst et al., 2008). The welfare state was thus at risk of becoming unsustainable. The increasing burden of non-wage labor costs to cover deficits in social insurance seriously jeopardized international competitiveness. ${ }^{1}$ When

\footnotetext{
${ }^{1}$ The situation was exploding since mainly workers financed the costs of German reunification through non-wage labor costs (see Riphahn et al., 2001). As a consequence, labor demand was falling.
} 
considering this institutional setting, there was considerable scope and a strong need for structural reforms in terms of both passive labor market policies (PLMP) and active labor market policies (ALMP).

With respect to PLMP, the unlimited payment duration of unemployment benefits and unemployment assistance was an extraordinary feature of the German system (Caliendo and Hogenacker, 2012). The replacement rates for the long-term unemployed were higher than in any other OECD country, while replacement rates for the short-time unemployed were comparable to many other countries (Eichhorst et al., 2008). As a result, the incentives to take up a job were very low, especially for the low-skilled and long-term unemployed. Generous benefit levels and benefit durations, combined with high benefit reduction rates if taking up employment, resulted in a growing and enduring base level of unemployment.

The approach towards ALMP was characterized by high expenditure levels and programs with rather long durations. The most important programs were job creation schemes and training programs, while programs such as job search assistance and monitoring were given low priority. Sanctions were rarely implemented. Additionally, the assignment process into programs was based on the caseworkers' discretion and no systematic individual profiling took place. There was also no systematic approach with respect to assessing the programs' effectiveness and efficiency. Although evaluation studies had been available (Caliendo and Steiner, 2005), their-mainly indicative-results had essentially no impact on the design, configuration or targeting of ALMP. 


\section{Successful Labor Market Reforms}

Against this background, major labor market reforms were introduced between 2003 and 2005. ${ }^{2}$ Implemented in four waves, these so-called Hartz reforms targeted three important areas that broadly affected the functioning of the labor market (Jacobi and Kluve, 2007). First, the reforms reorganized existing employment services and related policy measures. Importantly, unemployment benefit and social assistance schemes were restructured, and a means-tested flat-rate benefit replaced earnings-related, long-term unemployment assistance. Second, a significant reduction of long-term unemployment benefits - in terms of both amount and duration-and stricter monitoring activities were implemented to stimulate labor supply by providing the unemployed with more incentives to take up a job. Third, massive deregulation of fixed-term contracts, agency work and marginal part-time work was undertaken to stimulate labor demand. The implementation of the reforms in these three areas was tied to an evaluation mandate that systematically analyzed the effectiveness and efficiency of the various measures of ALMP.

Overall, the labor market reforms made Germany less vulnerable to economic shocks and, as it will be discussed in more detail below, they are therefore a key factor in explaining the country's remarkable resilience to the Great Recession. They successfully addressed the German labor supply problem as, among other things, work incentives for

\footnotetext{
${ }^{2}$ The reforms began with the famous speech of Gerhard Schröder ("Mut zum Frieden und Mut zur Veränderung") on March 14, 2003 which led to heated societal debates, public riots and terroristic attacks on those supporting the reforms. They split the Social Democratic Party, and even nowadays no major political party in Germany wants to openly identify itself with the labor market reforms-also not the currently ruling conservative party. To the contrary, there are repeated attempts to re-reform the measures which are unpopular and considered to be unsocial by large parts of the population.
} 
older workers were improved (early retirement options were phased out), ineffective policy instruments such as job creation schemes were abolished, long-term unemployment benefits were reorganized and reduced, and requirements for the unemployed to prove ongoing job search efforts were enforced. This resulted in an improved functioning of the German labor market with an increased overall effectiveness of ALMP (Eichhorst and Zimmermann, 2007), lower reservation wages of the unemployed (Schneider, 2008), and an accelerated matching process between unemployed workers and job vacancies (Fahr and Sunde, 2009).

Furthermore, population groups that had previously been characterized by comparatively low employment rates experienced substantial improvements in this regard. Figure 2 displays the development of the employment-to-population ratio for four important groups: female workers between 25 and 54 years, low-skilled workers between 20 and 64 years, older workers between 55 and 64 years, and younger workers between 15 and 24 years. For all four groups, increasing employment rates can be observed after the reforms were introduced. The increase was strongest among older workers, where employment increased by more than 20 percentage points between 2003 and 2011. ${ }^{3}$

$$
<<<\text { Figure } 2 \text { about here }>>>
$$

When considering the development of unit labor costs in Figure 3, the reforms apparently also contributed to Germany regaining its international competitiveness. Unit labor costs in Germany were persistently high for many years, but decreased after implementation of the reforms began in 2003. In

\footnotetext{
${ }^{3}$ Note that-according to various issues of the OECD International Migration Outlook - also the employment rates of foreign workers increased during that period (from 48 percent in 2005 to 57.8 percent in 2011 among female foreigners; and from 66 percent in 2005 to 75.6 percent in 2011 among male foreigners).
} 
contrast, unit labor costs increased continuously during the 2000s in, for example, the United States and the United Kingdom.

$$
<<<\text { Figure } 3 \text { about here }>>>
$$

It is important, however, to realize in this context that the underlying factor for the decline in unit labor costs did not stem primarily, as is widely believed, from wage restraint on the part of the trade unions. Union wages increased more moderately, but this explains only part of the decline. More important appears to be that unions and employers used the collective bargaining process to arrive at more flexible labor arrangements. This was, for example, possible via the socalled opening clauses in the contracts between unions and employers associations that are valid at times of crises. Such clauses became increasingly popular and are associated with greater wage dispersion and higher employment growth (Brändle et al., 2011). More generally, the more flexible labor arrangements allowed the adjustment, restructuring and reorganizing of existing work processes not only at the industry or sector level, but also at the firm level. In addition, East Germany developed into a region with low union coverage. This development was supported by the rise in employment in the service sector and the fall in employment in manufacturing, both of which made more and more jobs less regulated.

One may even argue that this newfound localized flexibility is the real source of the German model and, hence, of the country's resilience to the Great Recession. The recent increase of unit labor costs should be viewed in that light. It is - at least for the most part - a result of the various measures of internal flexibility used during the Great Recession. The next section discusses this issue in greater detail and in a broader context. 


\section{Stress Testing in the Great Recession}

Germany's labor market reforms, introduced between 2003 and 2005, were apparently successful. However, the worst global recession in postwar history constituted a strong test for the actual robustness of the economy and the labor market. During this critical period, the previous institutional changes and other adjustments had to prove that they indeed enhanced the functioning of the country's labor market-not only during a boom, but also when economic conditions become worse. Reform measures could act more effectively because the crisis made it more convincing that existing jobs, even if not attractive, had to be filled faster.

The Great Recession hit Germany mainly through declining exports. It arrived as a transitory external demand shock, which is different from what many other economies experienced. Figure 4 shows that output decline was at least as large as, for example, in the United States or in the United Kingdom. GDP decreased by 4.7 percent in 2009 relative to the previous year.

$$
<<<\text { Figure } 4 \text { about here }>>>
$$

This output decline was not homogeneous across Germany, and sectors and regions were affected to very different degrees (Rinne and Zimmermann, 2012). Output declines were most pronounced in export-oriented sectors such as manufacturing, where GDP dropped by about 18 percent in 2009. In contrast, sectors and industries related to private consumption were much less affected. For example, output in construction and in finance, renting and commercial services declined by less than 2 percent in 2009, while it even increased by about 2 percent in private and public services. Heterogeneous output declines can also be observed across German regions. Economically strong federal states, where many export-oriented firms are located, suffered the most 
(e.g., Baden-Württemberg), whereas federal states with low international exposure were less affected (e.g., Berlin, Brandenburg, Schleswig-Holstein). In addition, economic recovery took place relatively early. Already in the course of 2009, the economy was expanding again-although the recovery was strongest in those sectors that had experienced the sharpest declines. For example, manufacturing output increased by 11.5 percent in 2010. This quick recovery in Germany's export-oriented sectors appears related to the rather quick recovery of Asian economies that in turn boosted demand for German products (Bornhorst and Mody, 2012). These heterogeneous impacts, both during the crisis and recovery, support the notion that the Great Recession hit Germany as a transitory external demand shock. This is different from what many other countries experienced during the Great Recession, which were also affected through the housing, financial and consumer sectors.

However, the real distinctive feature of the German case is the remarkably mild response of its labor market to the substantial output drop. Both unemployment and employment remained largely unaffected by the adverse economic shock. Figure 5 shows that employment continued to rise and remained at a record level of more than 40 million throughout 2009 and 2010. In stark contrast, other countries experienced substantial employment declines. For example, employment dropped by about 6 percent in the United States and by about 2 percent in the United Kingdom.

$$
<<<\text { Figure } 5 \text { about here }>>>
$$

What factors explain the German success story during the Great Recession? A number of studies are directed at this important question (Möller, 2010; Burda and Hunt, 2011; Rinne and Zimmermann, 2012; Eichhorst, 2012; Bonin, 2012; Caliendo and Hogenacker, 2012). Representative of this literature, Rinne and Zimmermann (2012) argue that a 
combination of factors created an environment that is a challenge to replicate. Although the weight attached to each factor may differ across studies, the following aspects are considered as being highly relevant: The specific nature of the economic shock that hit Germany plays a role. Beyond that, the concrete policy responses during the critical period as well as the significant reforms that had improved the functioning and resistance of the country's labor market are essential. Long-term demographic trends that are expected to result in shortages of skilled labor are another factor. And ultimately, it is the combination of these different factors that resulted in employment adjustments mainly at the intensive margin-i.e., in Germany being a strong case of internal flexibility.

More specifically, because of the transitory external demand shock and the relative stability of private consumption, firms were more reluctant to lay off their workers. Although faced with substantial uncertainty, they largely viewed the shock to be only temporary and anticipated a rather quick recovery (Bornhorst and Mody, 2012). Hence, they wanted to preserve employees in the established core of their companies to remove the necessity - and costs - of hiring new personnel when demand improved.

Firms had the additional incentive to follow a strategy of adjusting employment at the intensive margin in response to the crisis because of shortages of skilled workers. As argued above, the extent of the output decline was heterogeneous across sectors; and at the sector level, there is a clear positive relationship between the share of firms that were strongly affected by the crisis and the share of firms reporting recruitment problems in 2008 (Möller, 2010). It is moreover expected that demographic changes will result in more severe shortages of skilled workers that will broadly affect the German labor market in the future. For example, the labor force is projected to shrink by almost 7 million workers by 2025 (Fuchs et al., 2011). 
These factors-expected quick recovery and recruitment problems - provided firms with the necessary incentives for internal flexibility. Besides these incentives, they also had the required financial resources to sustain a strategy of labor hoarding during the Great Recession. The successful labor market reforms have substantially improved the functioning of the labor markets and they helped firms to regain international competiveness. When the crisis started, the German economy (as well as individual companies) were thus in a relatively strong position. It is worth noting that the consumption sector with a large share of low-skilled workers and other workers at an above-average unemployment risk was unaffected by the crisis, and hence employment could even rise among the problem groups (unskilled, older workers, migrants) in the labor market.

In addition, firms had instruments available to reduce employees' working time at reasonable costs. They could achieve this on the one hand through a reduction of overtime hours and the use of other instruments of working time flexibility available at the firm level (e.g., working time accounts). On the other hand, they made extensive use of short-time work (Brenke et al., 2011). In fact, although German firms made ample use of all instruments to adjust at the intensive margin, short-time work appears to have been the quantitatively more important one. In 2009, the reduction in working hours due to working time accounts was about half of the size of the reduction due to short-time work (7.0 hours vs. 13.4 hours per employee; Zapf and Brehmer, 2010). Employees also worked, on average, 9.8 hours less in paid overtime in 2009 than in 2008. However, it seems that many firms followed a sequential approach in using the different instruments. First, they reduced overtime and used working time accounts. When individual accounts were close to zero, firms switched their strategy and used short-time work. 
It is therefore the combination and interaction of different factors that has resulted in German firms adjusting their employment levels during the Great Recession almost entirely at the intensive margin. But what if one or another factor had not been present during this critical period? This question can be answered by decomposing the impact of the Great Recession on employment and working hours into its components. More specifically, actual total working hours are used as the benchmark scenario, in which overtime reductions (possibly through working time accounts) and short-time work are sequentially removed-as if they would not have been available during this critical period.

Figure 6 displays the results of this exercise in terms of relative changes in total working hours and employment. These changes are compared to 2008, since employment and working hours were both still increasing in that year relative to 2007. A few developments are worth highlighting.

$$
<<<\text { Figure } 6 \text { about here }>>>
$$

First, actual total working hours decreased by more than 3 percent between 2008 and 2009. In stark contrast, employment remained remarkably stable in these years. This confirms the notion of internal flexibility playing an important role in Germany's resilience to the Great Recession.

Second, economic recovery translated into employment increases in both 2010 and 2011. Total working hours remained below the pre-recession level in 2010 and increased only by about half of the corresponding employment increase in 2011. Hence, employment increased both earlier and more strongly than working hours.

Third, the impact of reductions in overtime on working hours was substantial in 2009. These reductions accounted for about one-fifth of the total decrease in working hours in that year. Without these reductions, employment would have actually decreased by roughly half a percent. On the other 
hand, the reduction of overtime was not an important factor to the stabilization of employment in 2010 and 2011.

Fourth, the impact of short-time work on stabilizing employment was greater and lasted longer than the impact of reductions in overtime. In 2009, employment would have decreased by almost 1 percent had short-time work alone not been available. The combination of reductions in overtime and short-time work thus helped firms to preserve approximately 1.3 percent of their employees or more than half a million full-time workers. Short-time work also helped to stabilize employment in 2010. In terms of full-time equivalents, about 185,000 workers were affected in that year. Short-time work was less important in 2011.

The pattern in the use of short-time work and reductions in overtime is displayed in more detail in Figure 7. Both instruments for adjusting working time became relevant in the first quarter of 2009. However, it appears that reductions in overtime were essentially used only during three quarters, whereas short-time work had a longer-lasting impact. Adjustments in working hours using short-time work appear quantitatively important until the first quarter of 2011.

$$
<<<\text { Figure } 7 \text { about here }>>>
$$

While the remarkable resilience of Germany's labor market to the Great Recession was the result of various factors, one should try to distinguish between underlying long-term developments and policy responses during this critical period. Whereas the latter provided firms with the adequate instruments for adjusting employment almost entirely at the intensive margin in response to the crisis, the former factors were central for providing the required incentives and resources to do so in the first place. Next to long-term demographic changes, the successful labor market reforms should be regarded as an essential element. 
This issue is illustrated in Figure 8, which displays the development of the job openings rate and the long-term unemployment rate between 1991 and 2011. Long-term unemployment here refers to individuals who had been unemployed for at least one year. This is an important point in the German unemployment insurance system, as twelve months is the maximum benefit entitlement duration for unemployed individuals younger than 50 years. ${ }^{4}$ For longer durations of unemployment, workers have to rely on the means-tested flat-rate benefit scheme that was introduced with the labor market reforms.

$$
<<<\text { Figure } 8 \text { about here }>>>
$$

When using this definition, long-term unemployment had been steadily increasing during the first years after German reunification. During the economic expansion of 1998 to 2002, the number of long-term unemployed could be reduced, but their number continued to increase until 2005-the year when the labor market reforms had been fully implemented. Since then, a remarkable decrease in long-term unemployment can be observed. In a period of just six years, the long-term unemployment rate in Germany fell by more than 50 percent-from 5.9 percent in 2005 to 2.8 percent in 2011. Importantly, this decline continued even during the Great Recession, whose impact becomes nevertheless apparent with a (temporary) drop in the job openings rate.

The latter finding is particularly remarkable in comparison with what was happening in other countries. Figure 9 compares the job openings rates and the long-term unemployment rates of Germany and the United States (using

\footnotetext{
${ }^{4}$ See Caliendo and Hogenacker (2012, Table 1) for an overview about the maximum entitlement durations before and after the reforms. These durations depend on previous employment and age. Although they were generally reduced after the reforms, unemployed individuals older than 58 years can still be entitled to receive benefits for up to 24 months.
} 
the American definition of long-term unemploymentindividuals who are out of work for six months or longer-for both countries). Remarkably, the current situation in Germany is very similar to the one the United States faces today. This is even more surprising when considering that the two countries were at strikingly different starting points before the Great Recession. Still, the consensus in the United States is that there is no reason to believe that the country's current long-term unemployment is structural; it is considered to be temporary. ${ }^{5}$ If so, one may argue that long-term unemployment in Germany has reached an internationally acceptable level.

$$
<<<\text { Figure } 9 \text { about here }>>>
$$

Between 2005 and 2007, the United States was in a situation characterized by a low long-term unemployment rate of less than 1 percent and a rather high and stable job openings rate of more than 3 percent. During the Great Recession, however, the job opening rates fell to less than 2 percent and the long-term unemployment rate steadily increased, peaking at 4.3 percent in the second quarter of 2010. Although the long-term unemployment rate in the United States could subsequently be reduced to about 3 percent, it is still about three times higher than its pre-crisis level.

In contrast, Germany managed to reduce long-term unemployment despite the Great Recession. Standing at almost 8 percent in late 2005, the long-term unemployment rate steadily decreased to roughly 3 percent. On the other hand, the pattern of the job opening rates in Germany is less clear. In any case, Germany managed to successfully tackle its structural unemployment problem even during the worst

\footnotetext{
${ }^{5}$ See Lazear and Spletzer (2012) or Yellen (2013). This is not the place to challenge this view; it may need some time to reveal the relevant factors.
} 
global recession in postwar history. This is evidence that structural unemployment has been reduced in Germany during the crisis, which underlines the effectiveness of structural reforms.

\section{Austerity and Fiscal Consolidation}

Because of this success story, Germany is widely perceived as a role model for many countries - not only in Europe. In this context, however, there is a popular myth that needs to be put into perspective. Austerity and spending cuts for their own sake were never the "German style," as it is now widely, but falsely believed. During the reform process, fiscal consolidation and growth-oriented structural labor market reforms were regarded as two integral parts of a successful economic package to stimulate the economy.

If only considering the raw numbers (that is, how GDP and government gross debt evolved over time), Figure 10 shows a relatively steady increase. Government gross debt increased in total by about 40 percent between 2000 and 2010 . While the increase was small between 2006 and 2008, that is, just before the Great Recession, there was a particularly strong increase in debt in 2009 and 2010.

$$
<<<\text { Figure } 10 \text { about here }>>>
$$

Recent figures indicate that Germany's total government gross debt-to-GDP ratio was more than 80 percent in 2010 and around 78 percent in 2011 (BMF, 2013, Table 13b). This corresponds to a significant increase during the last decade. Furthermore, if this total debt were distributed across German regions, some federal states, such as Berlin and Bremen, would display debt-to-GDP ratios that are very similar to those of Ireland and Italy (DB Research, 2013). 
What are the underlying factors behind this increase? It could of course be the case that austerity was present in some kinds of government expenditures but not in others. Figure 11 provides a closer look at the development of expenditures for labor market programs in Germany. The structural labor market reforms could have been associated with adjustments in this area. Indeed, total expenditures for labor market policy decreased from roughly 3.5 percent of GDP to less than 2 percent between 2004 and 2008. In response to the crisis, however, expenditures increased again, peaking at about 2.5 percent of GDP in 2009. When distinguishing between expenditures related to ALMP and PLMP, it becomes apparent that both the decline and rise in total expenditures were governed by expenditures related to PLMP. It should be noted in this context that, despite total expenditures relating to ALMP not varying much from 2004 and 2010, expenditures on specific ALMP measures changed quite a bit over time. For example, costs for supported employment and rehabilitation as well as for direct job creation were markedly reduced in this period.

$$
<<<\text { Figure } 11 \text { about here }>>>
$$

Expenditures for labor market policy are related to the corresponding unemployment rate and should thus be put into this context. Moreover, it seems useful to compare the development in Germany to that in other European countries. This is portrayed in Figure 12, which shows that the development of expenditures for labor market policy in Germany is not all that exceptional compared to other European countries. It was, however, relatively high in 2005; and that was related to comparatively large spending on PLMP. In subsequent years Germany managed to cut overall spending on labor market policy, and in particular in the area of PLMP. This decrease was yet accompanied by declining unemployment, however. Hence, before the Great Recession 
started in 2007, Germany's expenditures for labor market policy were not markedly different from those in other European countries facing similar unemployment rates. In fact, expenditures and unemployment were very similar to those in France in that year. During the Great Recession, however, the two countries displayed somewhat different patterns. Whereas expenditures were increasing in a similar path in both countries, they were accompanied by stable unemployment in Germany and rising unemployment in France.

$$
<<<\text { Figure } 12 \text { about here }>>>
$$

One could thus argue that Germany increased expenditures on labor market policy during the Great Recession to successfully stabilize employment in this critical period, whereas other European countries (e.g., France) apparently increased expenditures in response to rising unemployment-or, put differently, at least without being able to effectively stabilize unemployment.

These considerations are in line with findings on the role of automatic stabilizers in the tax and transfer systems in different countries during the Great Recession (Dolls et al., 2012). The degree to which income and unemployment shocks are absorbed by the tax and transfer system is generally higher in the European Union than in the United States. This difference is larger for unemployment shocks, which can be explained by the relative importance of unemployment benefits. Furthermore, Germany exhibits relatively high income stabilization coefficients, both for income shocks and unemployment shocks, which are for example larger than those in France and the United Kingdom.

It is therefore important to realize the following additional two lessons from the German success story. First, the necessary efforts to reduce public budget deficits and to achieve fiscal stability do not rule out growth-oriented public 
investments. Second, while austerity is not a growth strategy per se, fiscal consolidation is a necessary condition to achieve future economic growth. Optimizing the use of public resources to foster growth makes sense only if it is combined with structural labor market reforms. Both are vital to the economy, which-like the human body-requires constant exercise and monitoring to get into and stay in shape.

\section{Lessons from the German Experience}

The development of Germany's labor market during the past decade is remarkable from many perspectives. It is remarkable because the country managed to successfully tackle its structural unemployment problem-and not only during periods of economic booms, but also during the worst global recession in postwar history. This paper identifies a number of crucial characteristics that make Germany a strong reference model for other countries. These characteristics include a flexible management of working time (through overtime and short-time work, time accounts and labor hoarding), social cohesion and controlled unit labor costs combined with a rigid incentive-oriented labor policy supported by effective program evaluation.

Considering the initial question of this paper, Germany does indeed appear to be the North Star of labor policy. In terms of long-term unemployment, the current situation in Germany is very similar to that of the United States. This is very surprising when considering that the two countries were at strikingly different starting points before the Great Recession. The economic crisis acted as a very strong test for the actual robustness of the economy. During this critical period, institutional changes and other adjustments dating from the early 2000s had to prove that they indeed could enhance the functioning of the country's labor market. And 
apparently, they did. Although discretionary measures such as the extension of short-time work helped cushion the impact of the crisis on Germany's labor market, these measures could not have contributed to the observed continuous decline in long-term unemployment.

This paper furthermore supports the argument that the German success story is mainly due to a combination of structural labor market reforms and the absence of fiscal austerity. There were no spending cuts for their own sake, but rather adjustments and consolidation of previous spending levels. That means, for example, in the context of labor policy that the importance of specific measures changed over time. Ineffective policy instruments were abolished or their scope substantially reduced (e.g., job creation schemes), whereas other measures and programs, mainly of short duration, gained importance (e.g., job search assistance, monitoring).

Germany's remarkable resilience to the Great Recession raises the question whether this apparent success can be effectively replicated by other countries. This paper argues that although, in general, this is not possible, there are many features of the German model that other countries should closely investigate. However, one should resist the temptation of believing in a one-size-fits-all solution. Instead, models for a given context have to be developed, which can yet be inspired by many features of the German model. In fact, to copy and steal what works in other countries is the bottom line of evidence-based policymaking - and also of the German experience. 


\section{References}

Blanchard, Olivier J. and Lawrence H. Summers (1986): "Hysteresis and the European Unemployment Problem," NBER Macroeconomics Annual 1986, Vol. 1, pp. 15-90.

BMF (2013): "Monatsbericht des BMF Januar 2013," Federal Ministry of Finance (BMF).

Bonin, Holger (2012): "The Two German Labour Market Miracles: Blueprints for Tackling the Unemployment Crisis?," Comparative Economic Studies, Vol. 54, No. 4, pp. 787-807.

Bornhorst, Fabian and Ashoka Mody (2012): "Tests of German Resilience," IMF Working Paper No. 12/239.

Brändle, Tobias, Wolf Dieter Heinbach, Michael F. Meier (2011): Tariflich Öffnung in Deutschland: Ausmaß, Determinanten, Auswirkungen (Flexibilisation in the German System of Wage Bargaining: Extent, Determinants, Impacts), " Journal for Labour Market Research, Vol. 44, No. 1/2, pp. 163-172.

Brenke, Karl, Ulf Rinne and Klaus F. Zimmermann (2011): "Short-Time Work: The German Answer to the Great Recession," IZA Discussion Paper No. 5780.

Burda, Michael C. and Jennifer Hunt (2011): "What Explains the German Labor Market Miracle in the Great Recession?," Brookings Papers on Economic Activity, Vol. 42, No. 1, pp. 273-335.

Caliendo, Marco and Viktor Steiner (2005): "Aktive Arbeitsmarktpolitik in Deutschland: Bestandsaufnahme und Bewertung der mikroökonomischen Evaluationsergebnisse," Journal for Labour Market Research, Vol. 38, No. 23, pp. 396-418.

Caliendo, Marco and Jens Hogenacker (2012): "The German Labor Marker after the Great Recession: Successful Reforms and Future Challenges," IZA Journal of European Labor Studies, Vol. 1, Article 3, pp. 1-24.

DB Research (2013): "Verschuldung der Bundesländer - eine Frage des Blickwinkels," available at: http://www.dbresearch.de/MAIL/ DBR INTERNET DE-PROD/PROD0000000000301245.xhtml (last accessed: February 28, 2013).

Dolls, Mathias, Clemens Fuest and Andreas Peichl (2012): "Automatic Stabilizers and Economic Crisis: US vs. Europe," Journal of Public Economics, Vol. 96, No. 3-4, pp. 279-294.

Eichhorst, Werner and Klaus F. Zimmermann (2007): "And Then There Were Four... How Many (and Which) Measures of Active Labor Market Policy Do We Still Need?," Applied Economics Quarterly, Vol. 53, No. 3, pp. 243272.

Eichhorst, Werner, Maria Grienberger-Zingerle and Regina Konle-Seidl (2008): "Activation Policies in Germany: From Status Protection to Basic Income Support," in: Werner Eichhorst, Otto Kaufmann and Regina Konle-Seidl (Eds.): Bringing the Jobless into Work?, Berlin: Springer. 
Eichhorst, Werner (2012): "The Unexpected Appearance of a New German Model," IZA Discussion Paper No. 6625.

Fahr, René and Uwe Sunde (2009): "Did the Hartz Reforms Speed-Up the Matching Process? A Macro-Evaluation Using Empirical Matching Functions," German Economic Review, Vol. 10, No. 3, pp. 284-316.

Fuchs, Johann, Doris Söhnlein and Brigitte Weber (2011): „Projektion des Arbeitskräfteangebots bis 2050: Rückgang und Alterung sind nicht mehr aufzuhalten, "IAB Kurzbericht 16/2011.

IZA (2003): „Den Reformaufbruch wagen! Aufruf von 300 Ökonomen an die politischen Entscheidungsträger," available at: http://www.iza.org/de/ webcontent/news/archive/aufruf zur agenda 2010.pdf (last accessed: February 28, 2013).

Jacobi, Lena and Jochen Kluve (2007): "Before and After the Hartz Reforms: The Performance of Active Labour Market Policy in Germany, "Journal for Labour Market Research Vol. 40, No. 1, pp. 45-64.

Lazear, Edward P. and James R. Spletzer (2012): "The United States Labor Market: Status Quo or A New Normal?," NBER Working Paper No. 18386.

Möller, Joachim (2010): "The German Labor Market Response in the World Recession: De-mystifying a Miracle," Journal for Labour Market Research, Vol. 42, No. 4, pp. 325-336.

Rinne, Ulf and Klaus F. Zimmermann (2012): "Another Economic Miracle? The German Labor Market and the Great Recession," IZA Journal of Labor Policy, Vol. 1, Article 3, pp. 1-21.

Riphahn, Regina T., Dennis J. Snower and Klaus F. Zimmermann (2001): Employment Policy in Transition: The Lessons of German Integration for the Labour Market. Heidelberg: Springer.

Schneider, Hilmar (2008): "Die Veränderung der Lohnersatzleistungen und die Reform der Vermittlungsprozesse im SGB III," Vierteljahrshefte zur Wirtschaftsforschung, Vol. 77, No. 1, pp. 20-37.

Yellen, Janet L. (2013): "A Painfully Slow Recovery for America's Workers: Causes, Implications, and the Federal Reserve's Response," speech at the A Trans-Atlantic Agenda for Shared Prosperity conference sponsored by the AFL-CIO, Friedrich Ebert Stiftung, and the IMK Macroeconomic Policy Institute, Washington, D.C. (February 11, 2013), available at: http://www.federalreserve.gov/newsevents/speech/yellen20130211a.htm (last accessed: February 28, 2013).

Zapf, Ines and Wolfram Brehmer (2010): "Flexibilität in der Wirtschaftskrise: Arbeitszeitkonten haben sich bewährt," IAB Kurzbericht 22/2010.

Zimmermann, Klaus F. (2003): Reformen jetzt! So geht es mit Deutschland wieder aufwärts. Wiesbaden: Gabler. 
Figure 1: Unemployment in Germany (1960-2012)

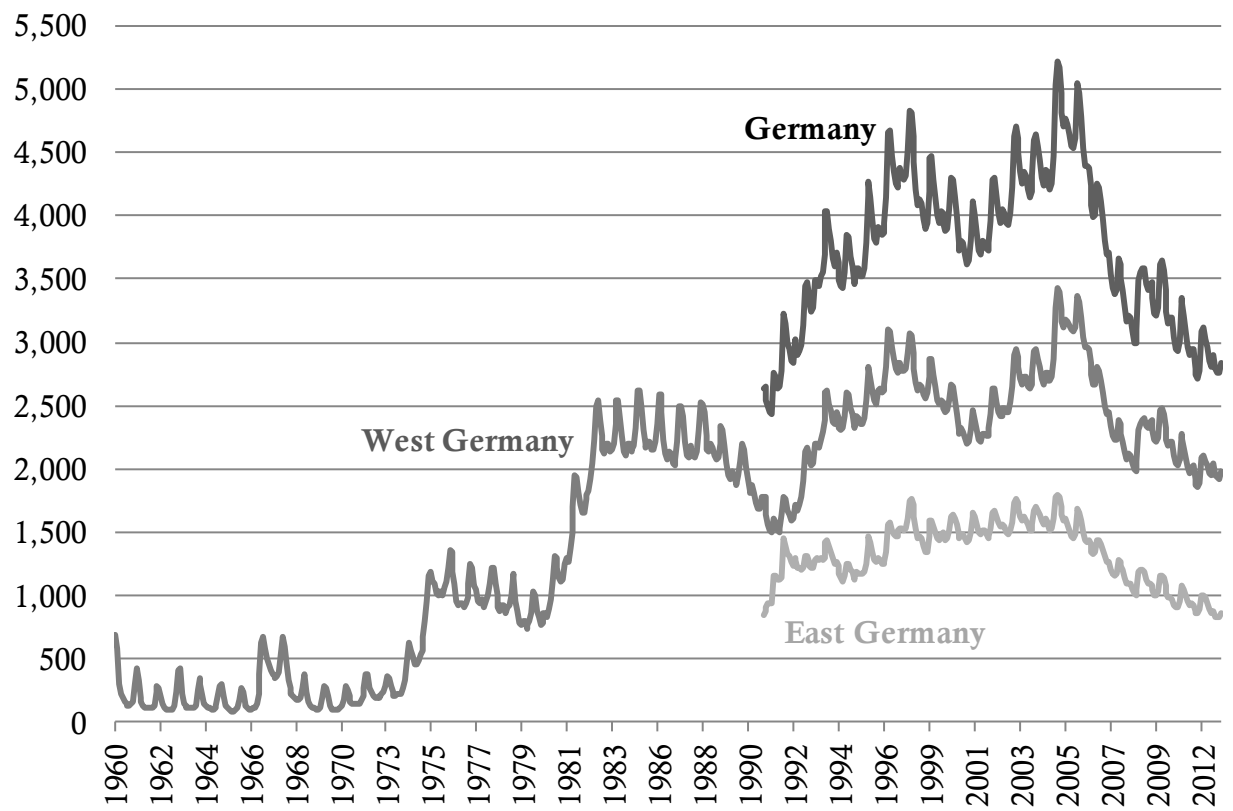

Source: Federal Statistical Office, Federal Employment Agency.

Notes: In thousands. Germany: since 1991 West-Germany (excl. Berlin) and East-Germany (incl. Berlin).

Figure 2: Employment/Population Ratio in Germany (2000-2011)

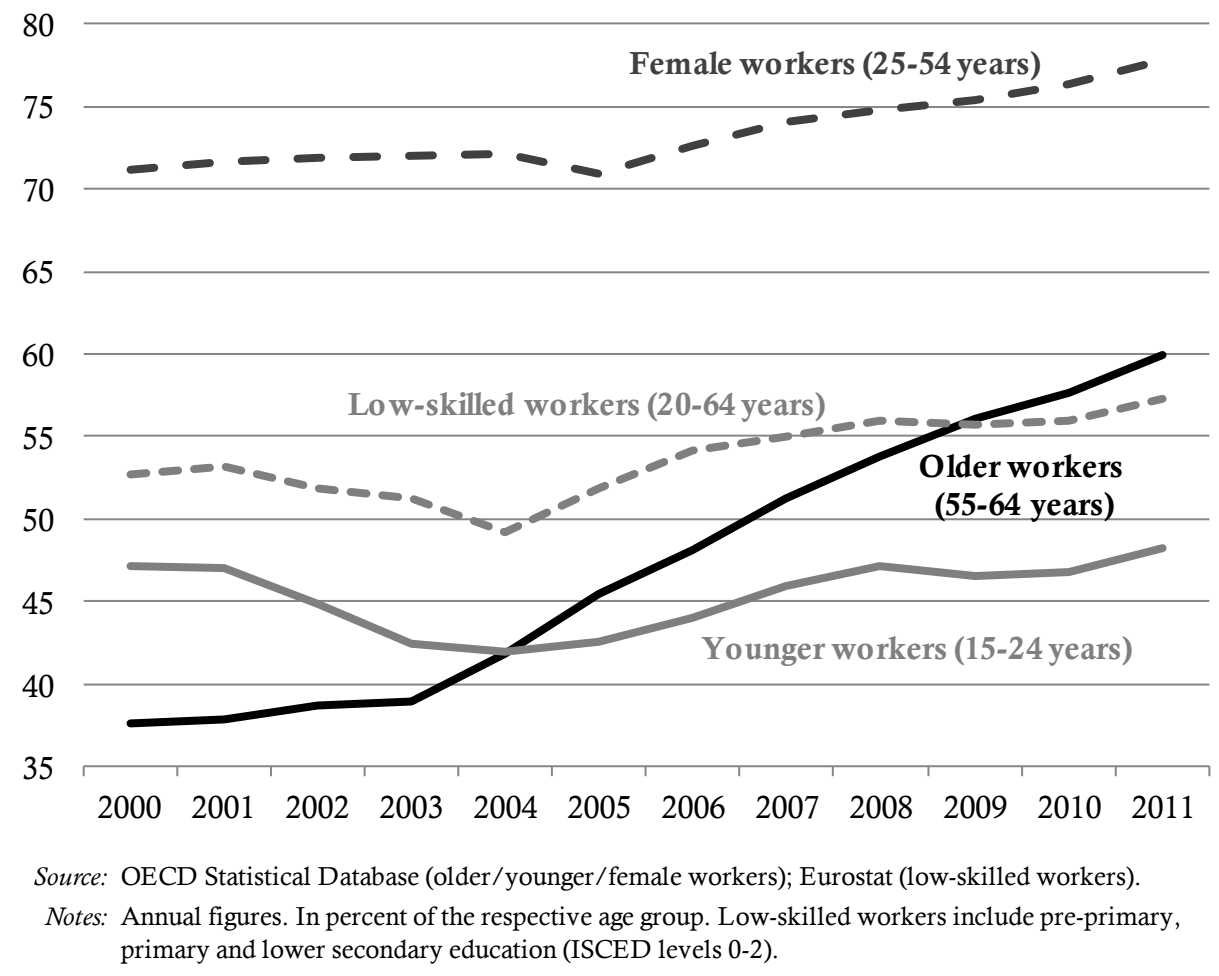


Figure 3: Unit Labor Costs, Total Economy (2005=100)

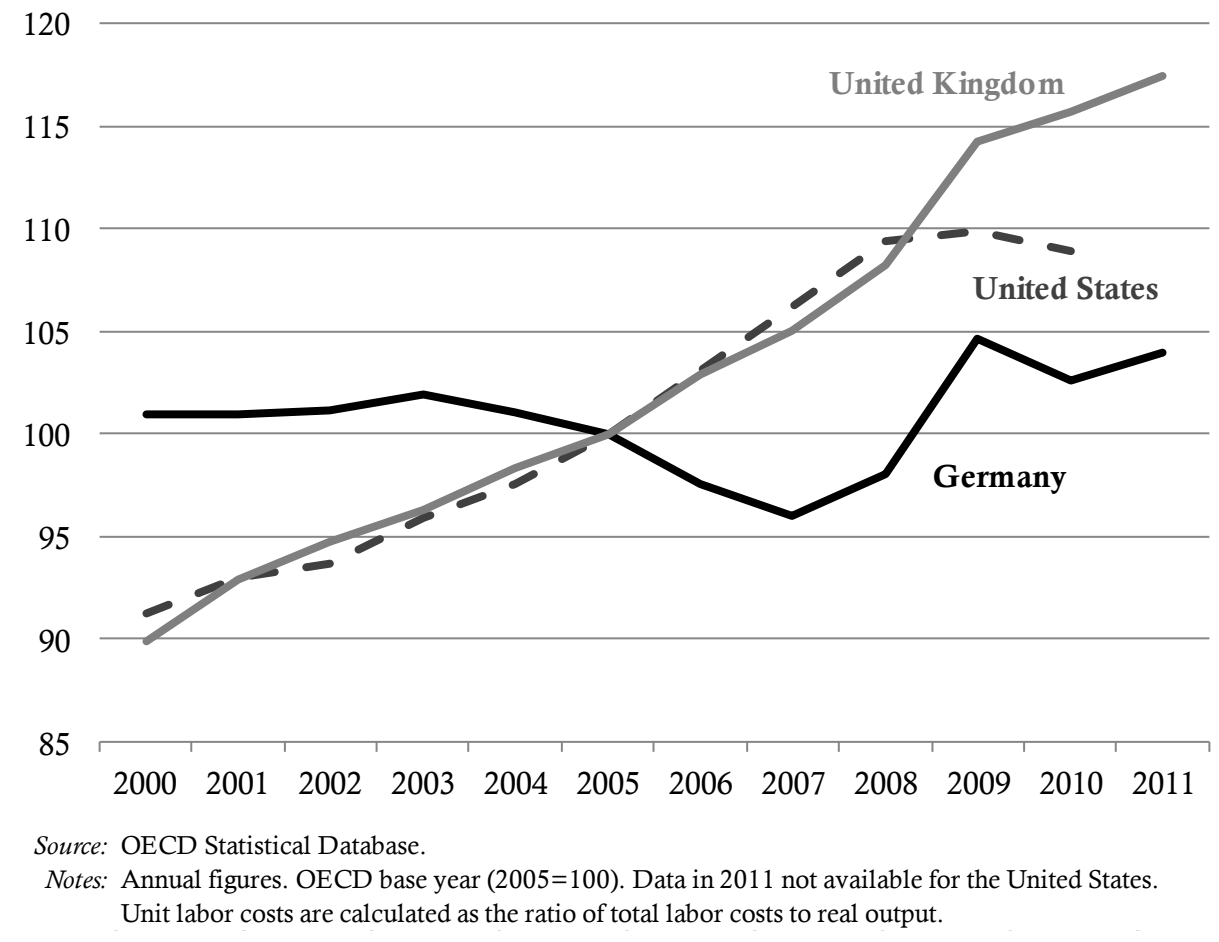

Figure 4: GDP Decline (GDP at Peak=100)

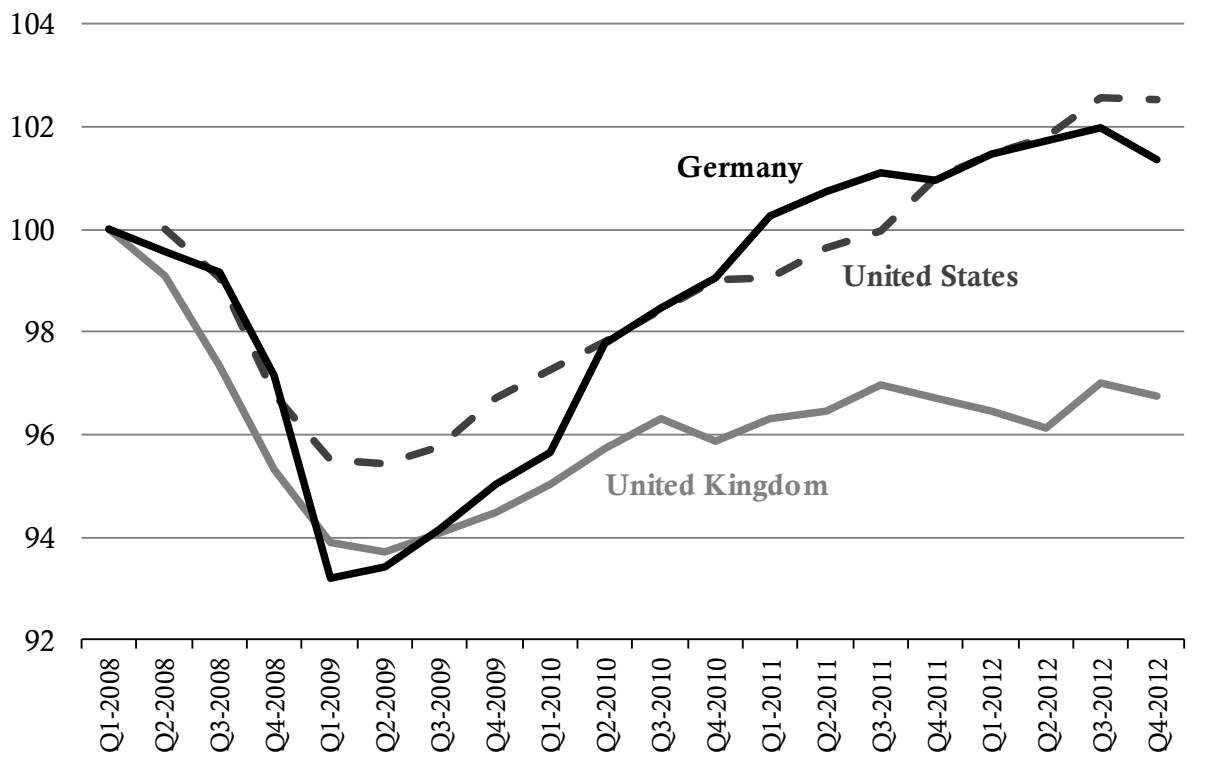

Source: OECD Statistical Database

Notes: The pre-recession peak is Q1-2008 for all countries except the United States, where it is Q2-2008. In millions of US dollars, volume estimates, fixed PPPs, OECD reference year, annual levels, seasonally adjusted. 
Figure 5: Employment (Employment at Peak=100)

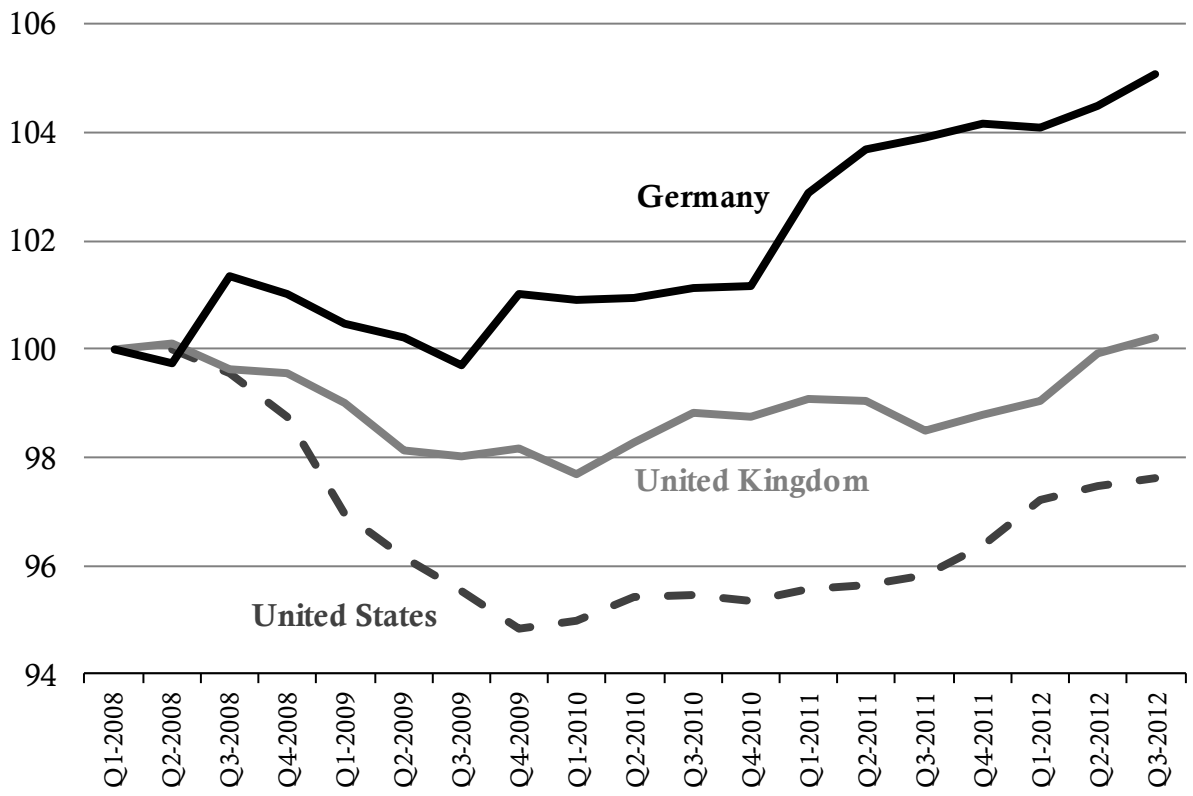

Source: OECD Statistical Database.

Notes: The pre-recession peak is Q1-2008 for all countries except the United States, where it is Q2-2008.

Civilian employment based on quarterly data. Quarterly averages of monthly data for the United States.

Figure 6: Annual Working Hours and Employment (2008=100)

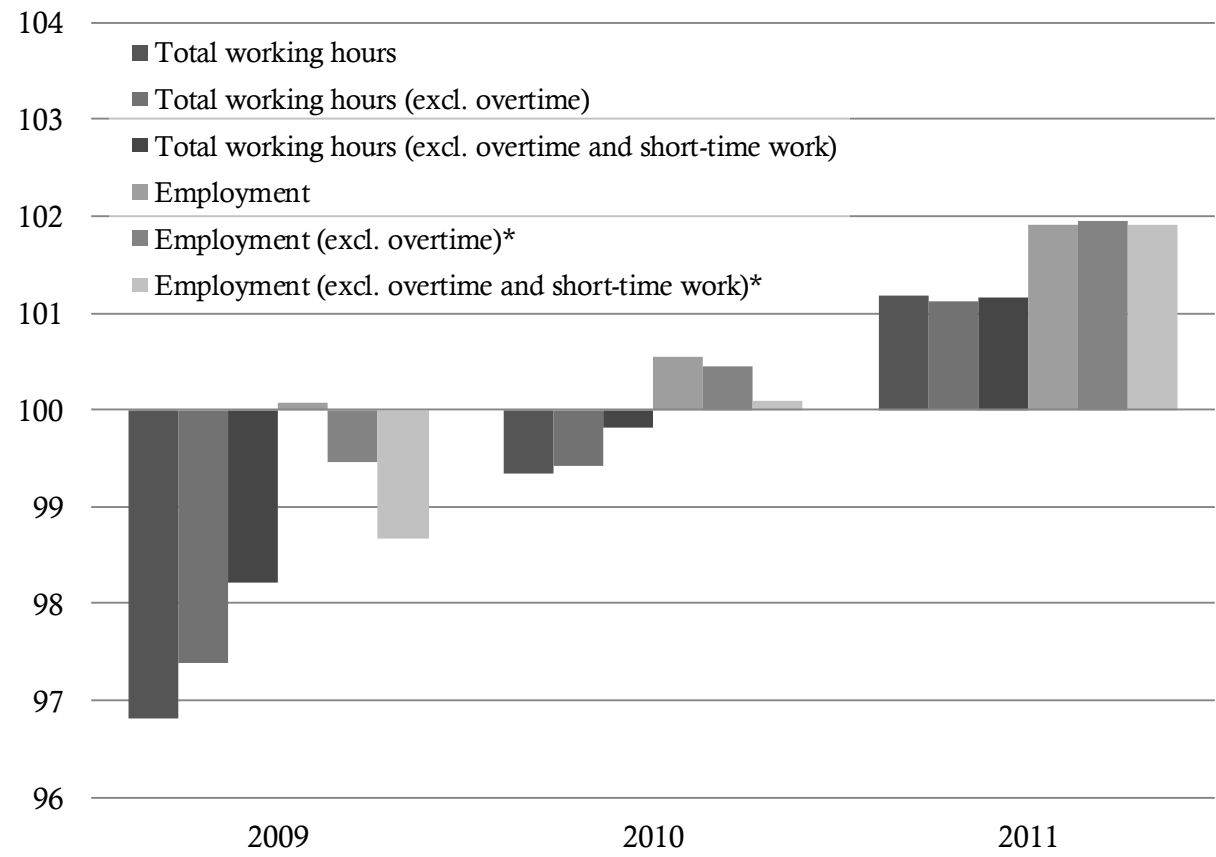

Source: IAB (http://doku.iab.de/grauepap/2012/tab-az11.pdf; last accessed: February 1, 2013), own calculations Notes: $2008=100$. Annual figures. Employment excludes self-employed.

* Under the assumption of constant average working hours (as of 2007). 
Figure 7: Overtime and Short-time Work by Quarter (2008-2012)

3.0

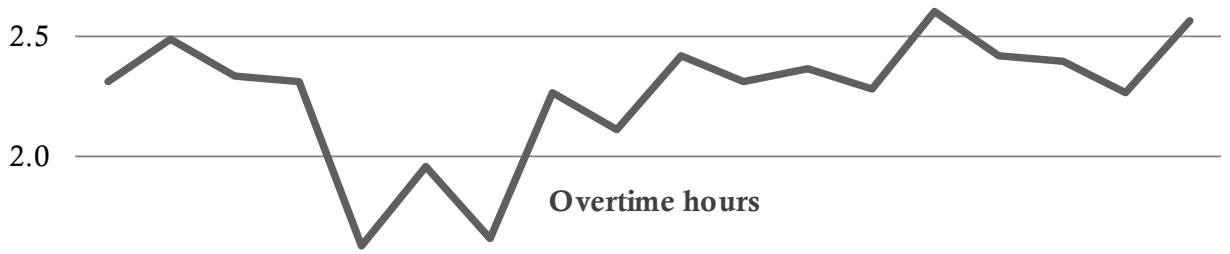

1.5

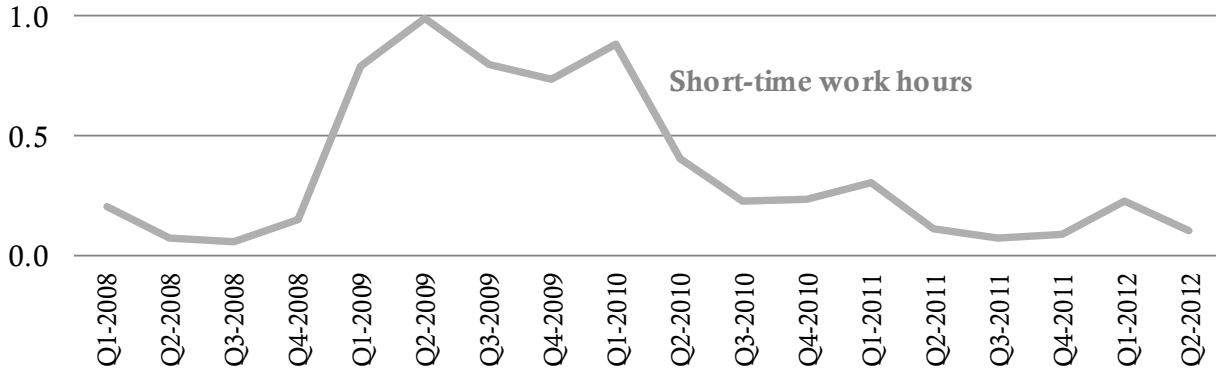

Source: IAB (http://doku.iab.de/grauepap/2012/tab-az1202.pdf; last accessed: February 1, 2013), own calculations. Notes: In percent of total working hours in a given quarter.

Figure 8: Job Openings and Long-Term Unemployment in Germany

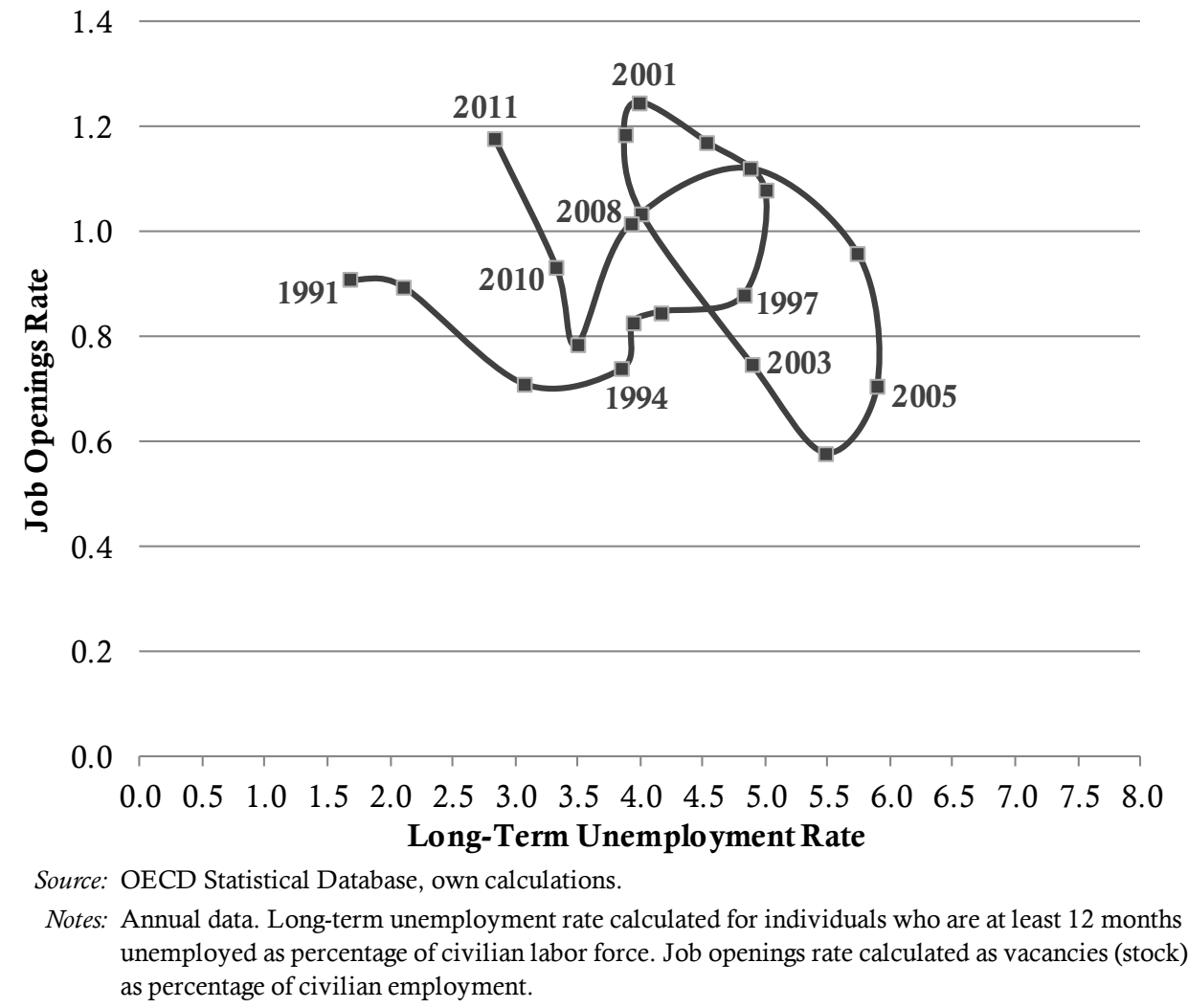


Figure 9: Job Openings Rate and Long-Term Unemployment Rate

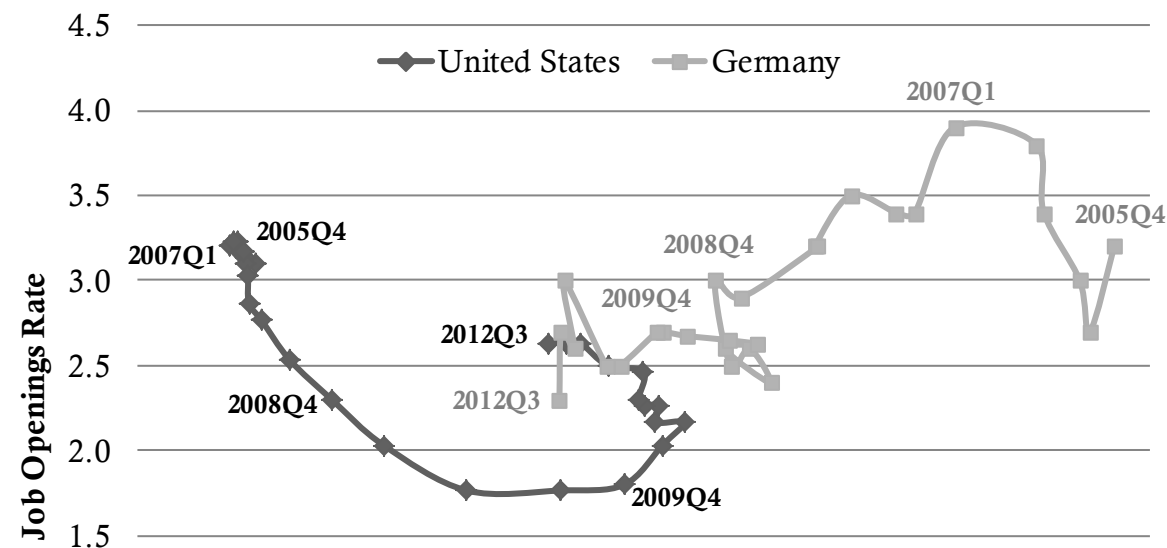

1.0

0.5

0.0

$\begin{array}{llllllllllllllllll}0.0 & 0.5 & 1.0 & 1.5 & 2.0 & 2.5 & 3.0 & 3.5 & 4.0 & 4.5 & 5.0 & 5.5 & 6.0 & 6.5 & 7.0 & 7.5 & 8.0\end{array}$

Long-Term Unemployment Rate

Source: Bureau of Labor Statistics, Eurostat, own calculations.

Notes: Quarterly data for Germany, quarterly averages (based on monthly data) for the United States.

Long-term unemployment rate calculated for individuals who are at least 6 months unemployed.

Job openings rate in Germany not avalaible from 2010Q1 to 2010Q3 (linear trend assumed).

Figure 10: GDP and Government Debt in Germany $(2000=100)$

150

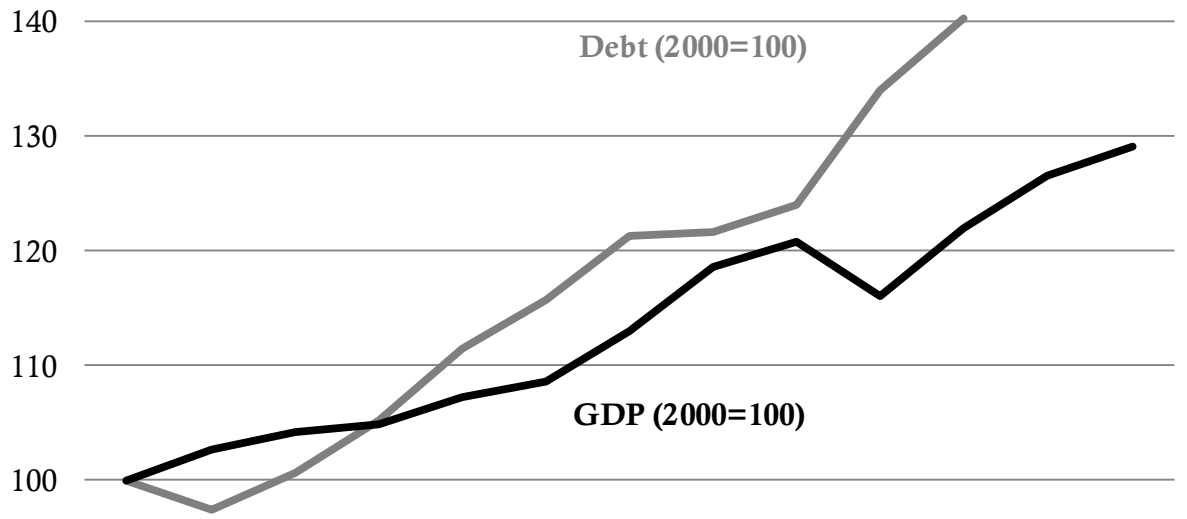

90

2000200120022003200420052006200720082009201020112012

Source: OECD Statistical Database.

Notes: Total central government debt, stocks: outstanding amounts, in millions of Euro $(2000=100)$. Data not yet available for $2011 / 2012$. Gross domestic product at current market prices, in millions of Euro, output approach $(2000=100)$. 
Figure 11: Expenditures for Labor Market Policy in Germany (2004-2010)

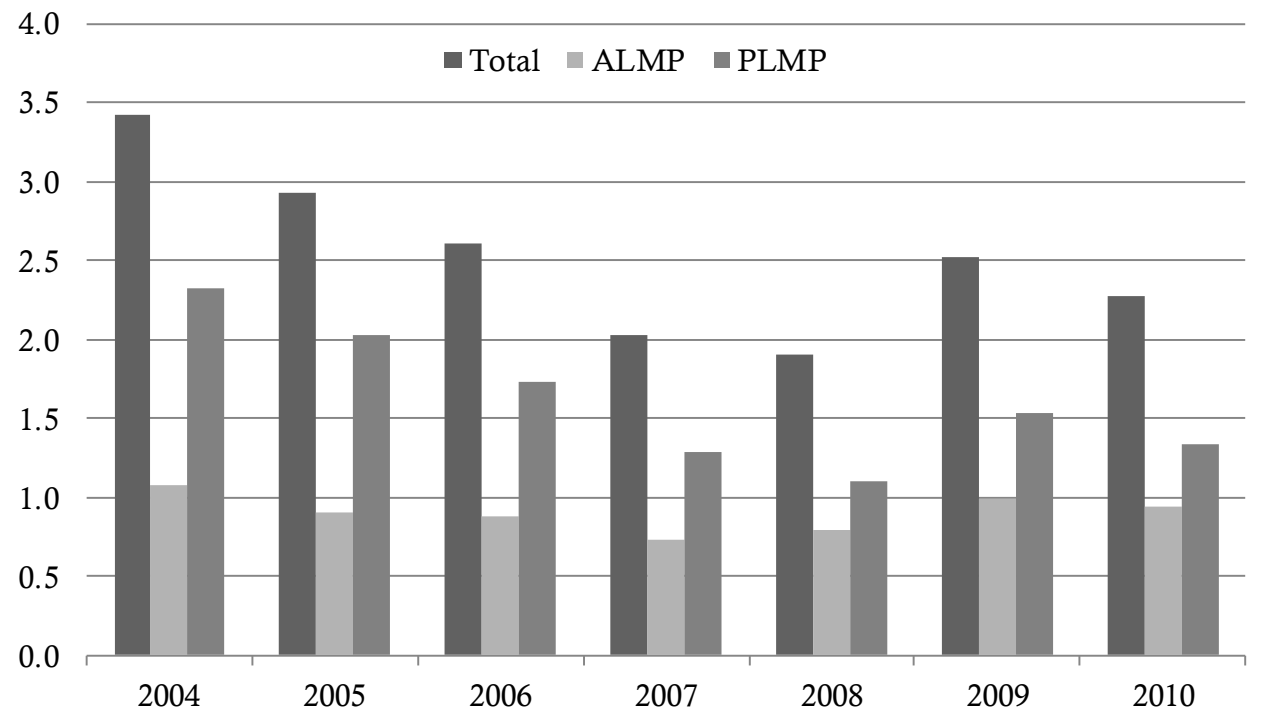

Source: OECD Statistical Database.

Notes: Public expenditures for total/active/passiv labor market policy as a percentage of GDP. 
Figure 12: Expenditures for Labor Market Policy vs. Unemployment Rate in European Countries (2005-2009)
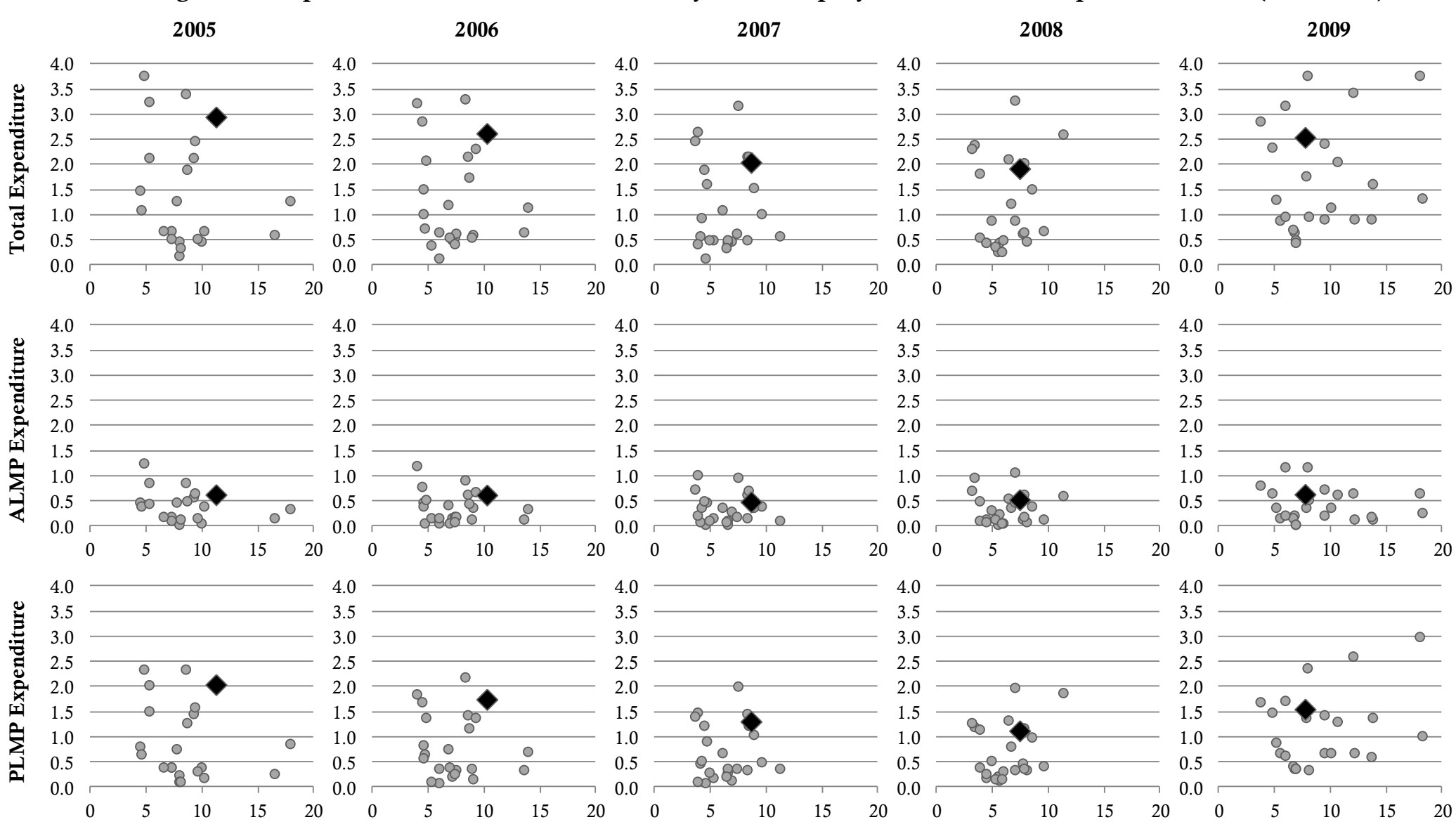

Source: EUROSTAT.

Notes: Vertical axis: public expenditures for total/active/passive labor market policy as a percentage of GDP. Horizontal axis: unemployment rate. Germany highlighted as black diamond. Other European countries (gray circles) include Belgium, Bulgaria, Czech Republic, Denmark, Estonia, Ireland, Greece, Spain, France, Italy, Cyprus, Latvia, Lithuania, Luxembourg, Hungary, Malta, the Netherlands, Austria, Poland, Portugal, Romania, Slovenia and Slovakia. 